Vol. 2 No. 1 Januari 2022 e-ISSN : 2774-6283 | p-ISSN : 2775-0019

\title{
MENINGKATKAN KETERAMPILAN MEMBACA MELALUI PENERAPAN METODE SQ3R PADA SISWA KELAS X SMK MUHAMMADIYAH WATANSOPPENG
}

\author{
RUSBAENA \\ SMK Muhammadiyah Watansoppeng \\ e-mail rusbaena@gmail.com
}

\begin{abstract}
ABSTRAK
Penelitian ini dimaksudkan untuk meningkatkan keterampilan membaca peserta didik melalui implementasi metode SQ3R (Survey, Question, Read, Recite, Review). Jenis penelitian ini adalah penelitin tindakan kelas (classroom action research) yang dilaksanakan di SMK Muhammadiyah Watansoppeng. Subyek penelitian adalah siswa kelas X SMK Muhammadiyah Watansoppeng Tahun pelajaran 2021/2022 yang terdiri dari 17 siswa, 9 laki-laki dan 8 perempuan. Penelitian tindakan kelas ini dilaksanakan sejumlah dua siklus yang mana pada setiap siklusnya mengikuti tahap perencanaan, pelaksanaan, observasi dan refleksi. Untuk análisis data penulis gunakan análisis kuantitatif. Hasil penelitian ditemukan bahwa penggunaan metode SQ3R dapat meningkatkan keterampilan membaca peserta didik kelas X SMK Muhammadiyah Watansoppeng. Peningkatan tersebut dapat dilihat dari hasil análisis data siklus 1 dengan rata-rata perolehan 79,23 serta persentase ketuntasan 70,59\%. Perolehan skor terendah yaitu 70 dan skor tertinggi yaitu 90 dengan median 79. Sedangkan pada siklus 2 ratarata skor perolehan yaitu 89,29 , skor terendah yaitu 80 dan skor tertinggi 98 , median sebesar 90 serta persentase ketuntasan yaitu $100 \%$.
\end{abstract}

Kata Kunci: Keterampilan membaca, metode SQ3R

\section{ABSTRACT}

This study is intended to improve students' reading skills through the implementation of the SQ3R method (Survey, Question, Read, Recite, Review). This type of research is classroom action research which is carried out at SMK Muhammadiyah Watansoppeng. The research subjects were students of class X SMK Muhammadiyah Watansoppeng for the academic year 2021/2022 which consisted of 17 students, 9 males and 8 females. This classroom action research was carried out in a number of two cycles, in which each cycle followed the stages of planning, implementation, observation and reflection. Analyze data using quantitative analysis. The results showed that the application of the SQ3R method could improve the learning outcomes of class X students of SMK Muhammadiyah Watansoppeng. This increase can be seen from the results of the data analysis cycle 1 with an average acquisition of 79.23 and the percentage of completeness $70.59 \%$. The lowest score is 70 and the highest score is 90 with a median of 79 . While in cycle 2 the average score is 89.29 , the lowest score is 80 and the highest score is 98 , the median is 90 and the percentage of completeness is $100 \%$.

Keywords: Reading skill, SQ3R method.

\section{PENDAHULUAN}

Salah satu tujuan pembelajaran bahasa Indonesia untuk jenjang Sekolah Menengah Kejuruan adalah untuk meningkatkan kemampuan peserta didik dalam berkomunikasi, baik secara tulisan maupun lisan. Peserta didik diarahkan bukan sekedar belajar teori bahasa akan tetapi juga untuk memiliki kompetensi dalam mengungkapkan makna dan pesan, termasuk di dalamnya adalah kemampuan untuk menafsirkan, menilai mengepresikan diri dengan bahasa. Hal tersebut dimaksudkan sebagai pondasi peserta didik untuk memahami dan merespon berbagai permasalahan terkait dengan situasi yang ada di daerah, yang sifatnya regional, nasional mauupun sifatnya global. Kemampuan berkomunikasi dapat juga disamakan dengan kemampuan berbahasa. Hal ini disebabkan karena lewat berkomunikasi tersebut orang menggunakan media bahasa sebagai instrumen pokoknya. Dengan demikian kemampuan 
berkomunikasi dapat dijabarkan sesuai dengan tingkat kemampuan berbahasa, yakni: kemampuan untuk menyimak, kemampuan untuk berbicara, kemampuan untuk membaca dan kemampuan yang berkaitan dengan menulis.

Kemampuan menyimak, berbicara, membaca dan menulis adalah merupakan faktor pendukung dalam menyampaikan pikiran, gagasan dan pendapat dalam bentuk tulisan dan lisan. Tentu hal tersebut menjadi penting bagi penggguna bahasa itu sendiri dalam memilih dan menggunakan kemampuan tersebut. Pengunaan bahasa oleh pengguna bahasa adalah merepresentasikan hasil pemikirannya. Sehingga kejelasan dan keterampilan dalam berbahasa menunjukkan seberapa baik jalan pikiran orang tersebut menggunakan bahasa. Dengan semakin banyak berlatih maka semakin memungkinkan untuk menguasai keterampilan berbahasa. Disinilah peran sentral seorang guru untuk meningkatkan keterampilan tersebut.

Salah satu keterampilan yang penting dalam pelajaran Bahasa Indonesia untuk dilatihkan terhadap peserta didik adalah keterampilan membaca. Hal tersebut dimaksudkan agar peserta didik tersebut dapat memiliki kemampuan dalam menganalisis dan memahami makna yang tersurat dan tersirat dalam wacana. Sebagaimana yang dikatakan oleh Hodgson yang dikutip oleh Agustina \& Hariyadi (2018, hal.70), bahwa aktivitas membaca adalah suatu kegiatan yang dilakukan oleh pembaca untuk mendapatkan pesan yang hendak disampaikan oleh penulis lewat penggunaan kata-kata atau bahasa tulis yang dipakai. Senada dengan pendapat tersebut, oleh Somadayo (2011) mengatakan bahwa kegiatan membaca adalah suatu aktivitas interaktif untuk memetik serta memahami arti yang terkandung di dalam bahan tulis.

Kehidupan manusia tidak terlepas dari aktivitas membaca dan olehnya itu keterampilan berbahasa tidak boleh diabaikan. Melalui kegiatan membaca manusia dapat meperoleh atau memenuhi kebutuhan tentang pengetahuan, pengalaman, informasi keterampilan dan sebagainya. Sebagaimana yang dikemukakan oleh Soedarso (2000, hal.4) bahwa dibutuhkan suatu kegiatan yang kompleks yang melibatkan proses berpikir. Dalam proses berpikir itu beberapa hal yang harus dilakukan antara lain bagaiman dapat mengingat sesuatu, bagaiman dapat memahami, bagaimana dapat membedakan, bisa membandingkan antar sesuatu, mampu menganalisis, dapat mengorganisasi yang akhirnya mampu mengimplementasikan apa yang termaktub dalam wacana itu.

Uraian di atas menunjukkan betapa pentingnya membaca dalam kehidupan manusia. Maka wajarlah jika sering di ungkapkan yang menyatakan, bahwa hanya satu cara yang dapat dilakukan untuk melihat dunia secara persuasif dalam meningkatkan cara belajar khususnya peningkatan keterampilan membaca. Beberapa diantara kita yang membaca sebuah buku atau bacaan lain dengan cara membaca keseluruhan bacaan itu sekaligus. Langkah demikian dianggap sebagai cara yang bagus untuk memahami wacana. Akan tetapi anggapan itu adalah keliru, karena untuk memahami suatu wacana bukanlah sekedar membaca dibutuhkan keterampilan tertentu. Oleh karena itu guru di sekolah sebaiknya memperhatikan hal tersebut untuk meningkatkan pemahaman peserta didik terhadap suatu bacaan.

Penulis adalah guru mata pelajaran bahasa Indonesia di SMK Muhammadiyah Watansoppeng Sulawesi Selatan. Berdasarkan pengamatan terhadap kondisi yang diidealkan dan fakta yang dialami yaitu adanya kesenjangan bukan hanya pada aspek kognitif tetapi juga aspek afektif dan keterampilan. Aspek kognitif meliputi tingkat pengetahuan dan pemahaman, mencermati, menganalisis materi pelajaran yang telah disampaikan. Berdasarkan hasil penilaian tengah semester tingkat persentase peserta didik yang mencapai ketuntasan sebesar 66,66\%. Pada tingkat aspek keterampilan yaitu rendahnya keterampilan dalam mencipta, mencipta puisi, karangan deskriptif sedangkan pada aspek afektif yaitu berkurangnya penghormatan peserta didik terhadap guru, kedisiplinan yang rendah, budaya "mappatabe"( menghargai/menghormati) mulai berkurang di aktifitas sekolah.

Rendahnya tingkat persentase ketuntasan belajar peserta didik, salah satu faktor penyebabnya adalah penggunaan metode mengajar yang dilakukan oleh guru. Menurut Ahmadi \& Prasetyo (2005, hal.52) mengatakan bahwa metode mengajar adalah suatu pengetahuan tentang bagaimana cara mengajar yang dilakukan oleh seorang pendidik. Pengertian lain adalah 
teknik penyajian bahan pelajaran yang dilakukan oleh pendidik kepada peserta didik dalam kelas yang dilakukan baik secara individu maupun secara berkelompok. Sedangkan Djamarah (2006, hal.72) mengatakan bahwa metode dapat dimaknai sebagai suatu alat untuk mencapai tujuan pembelajaran. Dengan menggunakan suatu metode dengan baik, maka guru akan dapat mencapai tujuan pembelajaran yang telah ditetapkan. Metode dapat pula dimaknai sebagai pelicin dalam menggapai suatu tujuan. Berdasarkan hal tersebut dapat dimaknai bahwa dengan metode yang tepat maka tentu tujuan pembelajaran yang telah dirancang dalam suatu rencana pembelajaran akan mudah untuk dicapai.

Berdasarkan pendapat tersebut di atas dapat diterjemahkan bahwa metode pembelajaran sangat penting peranannya dalam pencapaian tujuan pembelajaran. Sehingga dengan demikian itu penulis mencoba mengoptimalkan hasil belajar peserta didik melalui implementasi metode Survey, Question, Read, Recall, Review( SQ3R). Harapan penulis adalah dengan diterapkannya metode ini maka tingkat pemahaman peserta didik terhadap suatu bacaan akan mampu ditingkatkan.

Hasil studi literatur yang berkaitan dengan efektivitas penggunaan metode ini, oleh beberapa peneliti sebelumnya telah dilakukan dan dipublikasikan seperti; penelitian oleh (Susanti, Purmintasari \& Suwarni, 2016, hal.97; Agustina \& Hariyadi, 2018, hal.79; Riadi, 2015, hal.137) menyimpulkan bahwa ada pengaruh penerapan metode pembelajaran SQ3R terhadap hasil belajar.

Penelitian ini adalah penelitian tindakan kelas yang tentu lokus penelitian berbeda dengan penelitian sebelumnya begitu juga dengan karakteristik subjek penelitian. Oleh karena itu menjadi penting untuk melakukan penelitian ini dengan menerapkan metode Survey, Question, Read, Recall, Review (SQ3R). Metode SQ3R (Survey Questions Read Recite Review) adalah suatu metode yang bertujuan untuk mempelajari suatu wacana dengan mengikuti langkah-langkah tertentu. Tahapa-tahapan yang dimaksud yakni melalui "survey" yang dimaksudkan sebagai suatu aktivitas untuk menelusuri dan melihat anatomi suatu bacaan. Selanjutnya langkah "question" yaitu sebuah tahap dimana pembaca diminta untuk mengajukan pertanyaan seperti" apa, siapa, kapan, dimana, mengapa dan bagimana" yang berkenaan dengan wacana yang telah dibaca. Tahap "read" adalah suatu proses membaca suatu bacaan. Pada langkah "recite" yaitu suatu tahapan yang meminta pembaca untuk mengungkapkan kembali dengan kata-kata sendiri terhadap hasil bacaan. Sedangkan tahap "review"adalah suatu langkah bagaimana pembaca diminta untuk kembali mengulang bacaan sekaligus merevisi kembali hasil jawaban yang ditemukan (National Behaviour Support Service, n.d.) Selanjutnya dalam buku tersebut dikemukakan alasan mengapa menggunakan metode SQ3R seperti berikut: dapat memberikan gambaran akan suatu bacaan; dapat mengatur bab, paragraph dalam kerangka yang menghubungkan antar potongan-potongan informasi baru; dapat memfokuskan membaca tentang "siapa, apa, kapan, di mana, dan bagaimana" untuk diidentifikasi dan dicari jawabannya; memberikan pengulangan dan latihan yang diperlukan untuk belajar; membantu pembaca mengingat apa yang perlu diketahuinya (National Behaviour Support Service, n.d.)

Berdasarkan pandangan di atas dapat dikemukakan manfaat menggunakan metode SQ3R antara lain: pertama, memberikan gambaran suatu bacaan dalam tahap Survey melalui Skimming text. Kedua, dapat menyatukan potongan-potongan informasi melalui tahap bertanya (Question) dengan cara mengajukan pertanyaan kepada diri sendiri apa yang telah dibaca. Ketiga, fokus membaca untuk menjawab pertanyaan, siapa, kapan, dimana, bagaimana dll melalui tahap membaca (Read). Keempat, memberikan pengulangan dan latihan yang diperlukan untuk belajar melalui tahap recite. Kelima, membantu pembaca mengingat apa yang perlu pembaca ketahui melalui tahap review. Dengan demikian, diharapkan penggunaan metode SQ3R ini dapat menunjang pembelajaran membaca kritis.

\section{METODE PENELITIAN}

Desain penelitian ini adalah desain penelitian tindakan kelas (Classroom Action Research) yang dilaksanakan sebanyak dua siklus. Dalam tiap siklus dilakukan melalui 4 
(empat) tahap yaitu perencanaan (Planning), tindakan (Action), Observasi (Observation), dan refleksi (Reflekction). Penelitian ini dilaksanakan di SMK Muhammadiyah Watansoppeng Tahun Pelajaran 2021/2022. Subjek penelitian yaitu siswa kelas X semester ganjil dengan jumlah 17 orang terdiri atas 9 laki-laki dan 8 perempuan. Untuk memperoleh data tentang keterampilan membaca maka digunakan instrument penelitian berupa soal essay test bacaan.

\section{HASIL DAN PEMBAHASAN}

Berdasarkan hasil penelitian ditemukan bahwa implementasi metode SQ3R bisa meningkatkan keterampilan membaca peserta didik pada kelas X SMK Muhammadiyah Watansoppeng. Hasil ini sesuai dengan hasil análisis siklus 1 dan siklus 2 yang mengalami peningkatan dari siklus 1 sebesar 75,59\% menjadi $100 \%$ pada siklus 2 . Hasil tersebut dapat dilihat pada gambar berikut:

\begin{tabular}{|c|c|c|c|}
\hline \multirow[t]{2}{*}{$\mathrm{N}$} & Valid & 17 & 17 \\
\hline & Missing & 0 & 0 \\
\hline \multicolumn{3}{|c|}{ Mean. } & 79,2353 \\
\hline \multicolumn{3}{|c|}{ Std.Error of Mean } & 1,44896 \\
\hline \multicolumn{3}{|c|}{ Median } & 79,0000 \\
\hline \multicolumn{3}{|c|}{ Mode } & $74,00^{\mathrm{a}}$ \\
\hline \multicolumn{3}{|c|}{ Std. Deviation } & 5,97421 \\
\hline \multicolumn{3}{|c|}{ Variance } & 35,691 \\
\hline \multicolumn{3}{|c|}{ Range } & 20,00 \\
\hline \multicolumn{3}{|c|}{ Mínimum } & 70,00 \\
\hline \multicolumn{3}{|c|}{ Maksimum } & 90,00 \\
\hline \multicolumn{3}{|c|}{ sum } & 1347,00 \\
\hline
\end{tabular}

Mencermati hasil statistik sebagaimana pada tabel 1 di atas nampak bahwa skor perolehan terendah pada siklus 1 yaitu 70 dan skor tertinggi yaitu 90. Nilai rata-rata perolehan siswa yaitu 79,23 dan nilai mode adalah 74. Nilai ketuntasan pada pelajaran bahasa Indonesia yaitu 75 dengan demikian beberapa siswa dinyatakan belum tuntas karena belum mencapai batas ketuntasan yaitu 75 .

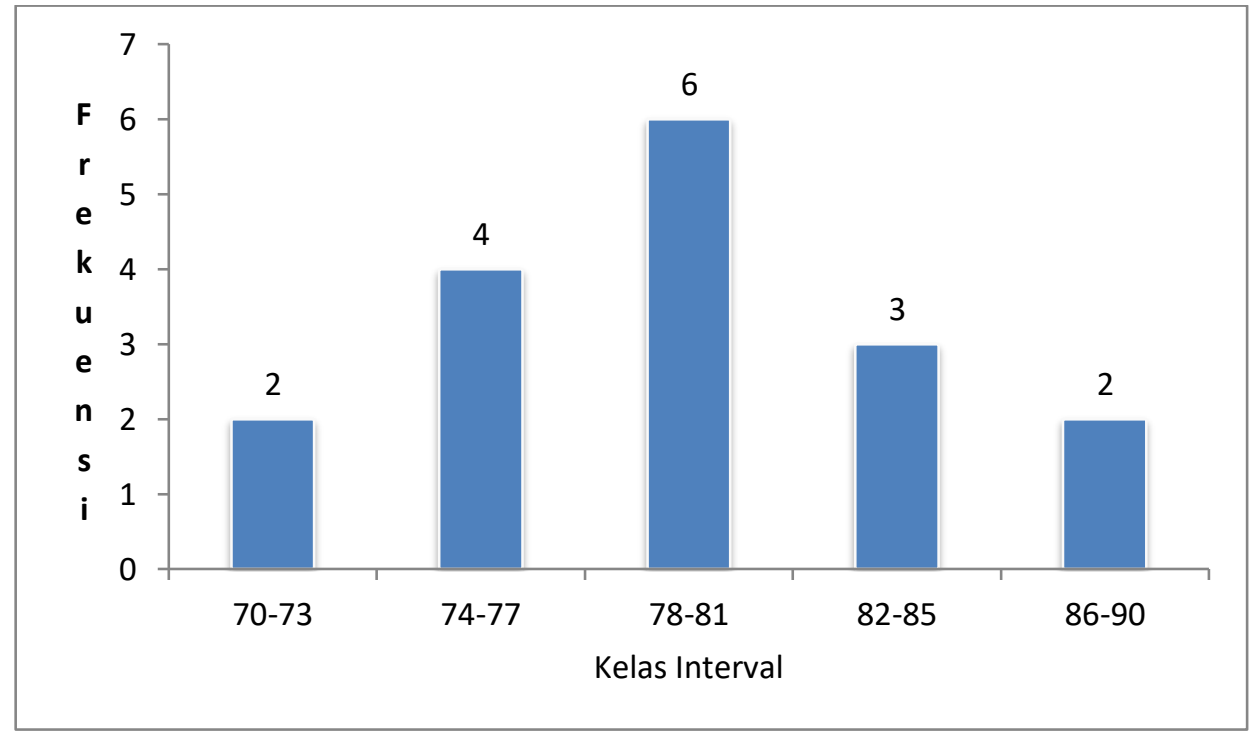

Gambar 1 Diagram Batang Keterampilan Membaca Siklus 1

Mencermati gambar $1 \mathrm{di}$ atas dapat dilihat bahwa keterampilan membaca siswa pada siklus 1 dengan skor terendah yaitu 70 dan skor tertinggi yaitu 90. Berdasarkan data tersebut selanjutnya dicari range yaitu nilai tertinggi-nilai terendah $=20$. Selanjutnya ditentukan banyak 
kelas dan panjang kelas. $\mathrm{K}=1+3,332 \mathrm{X} \log \mathrm{n}(17)=5$ dan panjang kelas yaitu range atau jangkauan /banyaknya kelas interval $=4$.Pada kelas interval terendah 70-73 sebanyak 2 siswa, pada kelas interval 74-77 sebanyak 4 siswa, kelas interval 78-81 sebanyak 6 siswa, kelas interval 82-85 sebanyak 3 siswa dan kelas interval 86-90 sebanyak 2 siswa. Kelas interval yang paling banyak jumlah frekuensi yaitu kelas interval 78-81 sebanyak 6 siswa, dan yang paling sedikit frekuensinya yaitu kelas interval 78-81 dan 86-90 sebanyak masing-masing 2 siswa.

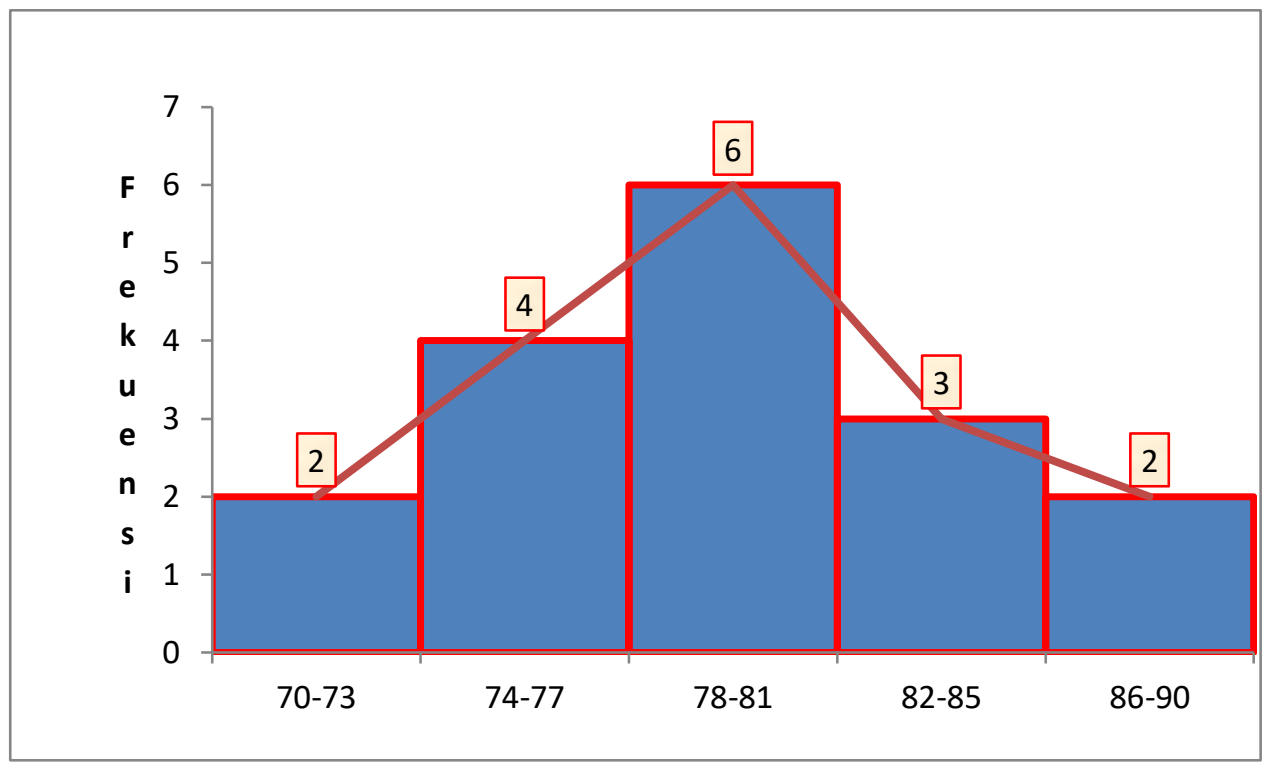

Gambar 2 Histogram Keterampilan Membaca Siklus 1

Mencermati hasil data sebagaiman pada gambar 2 tersebut di atas bisa dijelaskan bahwa sebaran data berpusat pada kelas interval di tengah yaitu 78-81 artinya data ini berdistribusi normal atau tidak ada data ekstrim baik pada kelas interval rendah maupun kelas interval tinggi.

Tabel 2 Persentase Ketuntasan Keterampilan Membaca Siklus 1

\begin{tabular}{|c|c|c|c|c|}
\hline No & Nilai & Siswa & persentase & Kategori \\
\hline 1 & $\mathrm{X} \geq 75$ & 12 & 70,59 & Tuntas \\
\hline 2 & $\mathrm{X}<75$ & 5 & 29,41 & Belum tuntas \\
\hline
\end{tabular}

Mencermati data pada tabel 1 di atas bisa dilihat bahwa persentase ketuntasan siswa mencapai 70,59\% dan ketidak tuntasan mencapai $29,41 \%$. Hasil tersebut cukup bagus akan tetapi belum mencapai ketuntasan klasikal sebesar $\geq 85 \%$ sebagaimana menurut Trianto bahwa ketuntasan klasikal terjadi jika di dalam kelas yang dinilai tersebut memiliki $\geq 85 \%$ peserta didik yang telah tuntas belajarnya (Trianto, 2010, hal.241). Oleh karena itu maka penelitian ini dilanjutkan pada siklus2.

Tabel 3 Perbandingan Statistik Siklus 1 dan 2

\begin{tabular}{|c|c|c|c|c|}
\hline \multirow[t]{2}{*}{$\mathrm{N}$} & Valid & 17 & 17 & 17 \\
\hline & Missing & 0 & 0 & 0 \\
\hline \multicolumn{3}{|c|}{ Mean. } & 79,2353 & 89,2941 \\
\hline \multicolumn{3}{|c|}{ Std.Error of Mean } & 1,44896 & 1,34154 \\
\hline \multicolumn{3}{|c|}{ Median } & 79,0000 & 90,0000 \\
\hline \multicolumn{3}{|c|}{ Mode } & $74,00^{\mathrm{a}}$ & 85,00 \\
\hline \multicolumn{3}{|c|}{ Std. Deviation } & 5,97421 & 5,53133 \\
\hline \multicolumn{3}{|c|}{ Variance } & 35,691 & 30,596 \\
\hline \multicolumn{3}{|c|}{ Range } & 20,00 & 18,00 \\
\hline \multicolumn{3}{|c|}{ Mínimum } & 70,00 & 80,00 \\
\hline \multicolumn{3}{|c|}{ Maksimum } & 90,00 & 98,00 \\
\hline
\end{tabular}


Mencermati data pada tabel 3 di atas bahwa ada peningkatan rata-rata perolehan peserta didik dari pembelajaran siklus 1 ke pembelajaran siklus 2 yaitu dari 79,23 menjadi 89,29 atau kenaikan sebesar 10,06. Untuk nilai tengah pada siklus 1 yaitu 79 sedangkan pada siklus 2 yaitu 90 atau mengalami peningkatan sebesar 11. Selanjutnya untuk mode juga mengalami peningkatan dari siklus 1 sebesar 74 dan siklus 2 menjadi 85. Untuk range (jangkauan) ada penurunan dari siklus 1 sebesar 20 menjadi 18 pada siklus 2 dan hal ini mengindikasikan bahwa sebaran data, selisih antara data tertinggi dan terendah semakin berkurang. Nilai mínimum pada siklus 1 sebesar 70 dan siklus 2 menjadi 80 yang berarti mengalami peningkatan. Demikian pula nilai maksimum pada siklus 2 mengalami peningkatan dari 90 siklus 1 menjadi 98 siklus 2. Untuk ukuran jumlah perolehan skor dari siklus 1 sebesar 1347 menjadi 1518 atau mengalami peningkatan angka sebesar 171 .

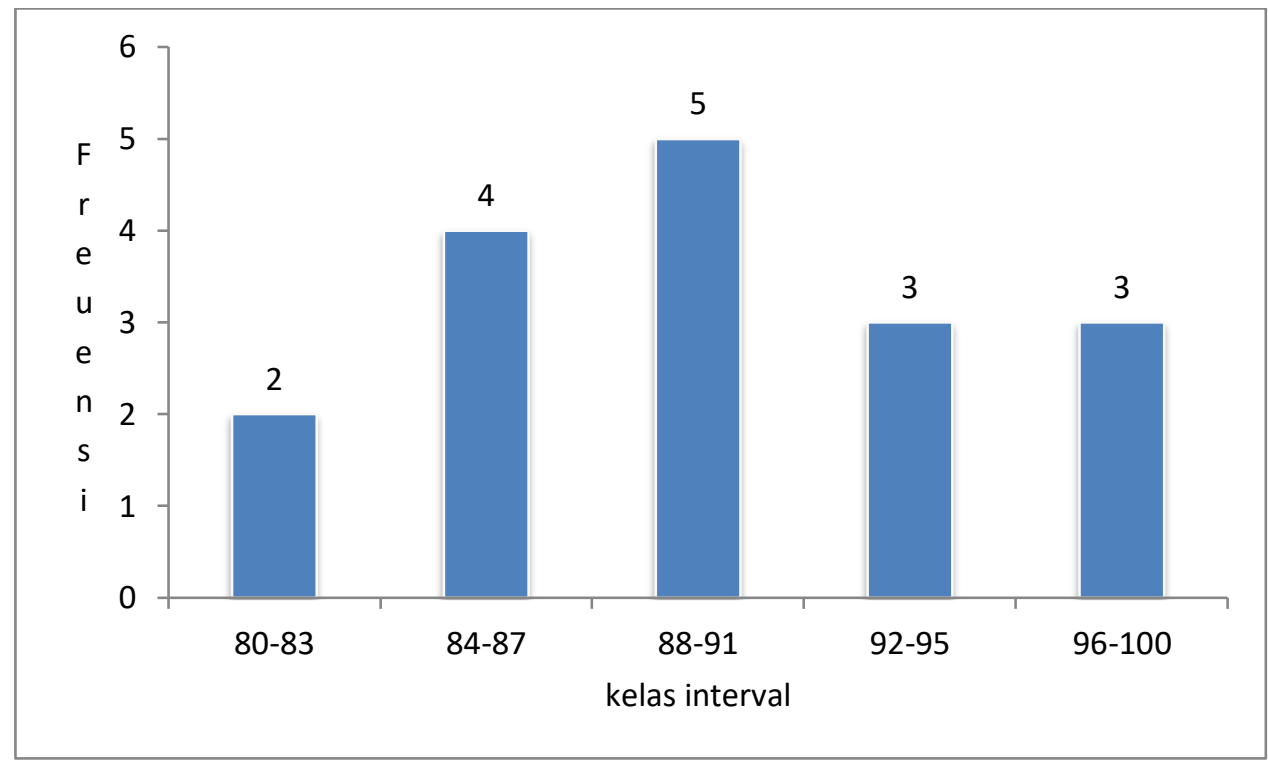

\section{Gambar 3 Diagram Batang Keterampilan Membaca Siklus 2}

Mencermati gambar 3 di atas dapat dilihat bahwa keterampilan membaca siswa pada siklus 2 pada kelas intervail terendah yaitu 80-83 sebanyak 2 siswa, pada kelas interval 84-87 sebanyak 4 siswa, kelas interval 88-91 sebanyak 5 siswa, kelas interval 92-95 sebanyak 3 siswa dan kelas interval 96-110 sebanyak 3 siswa. Kelas interval yang paling banyak jumlah frekuensi yaitu kelas interval 88-91 sebanyak 5 siswa, dan yang paling sedikit frekuensinya yaitu kelas interval 80-83 sebanyak 2 siswa. 


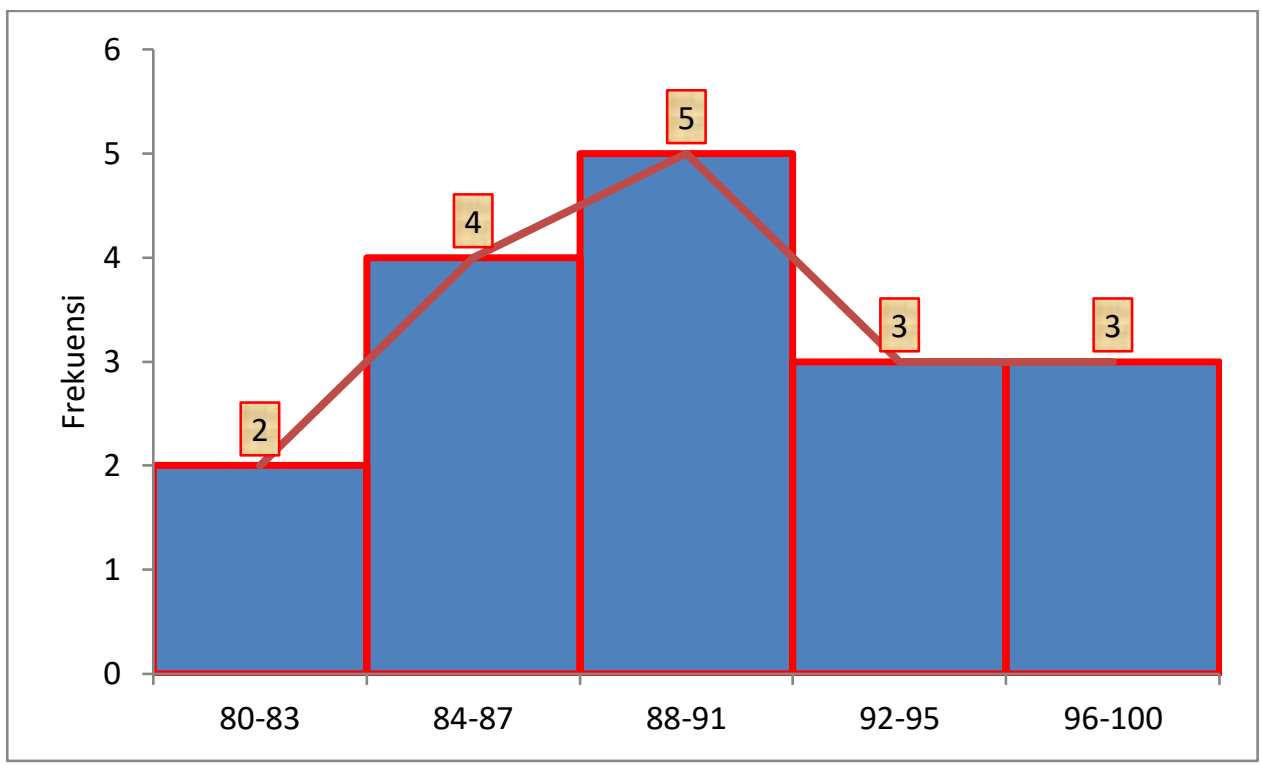

Gambar 4 Histogram Keterampilan Membaca Siklus 2

Mencermati data pada gambar 4 tersebut di atas dapat dijelaskan bahwa sebaran data berpusat pada kelas interval di tengah yaitu 88-91 artinya data ini berdistribusi normal atau tidak ada data ekstrim baik pada kelas interval rendah maupun kelas interval tinggi.

Tabel 4 Persentase Ketuntasan Keterampilan Membaca Siklus 2

\begin{tabular}{|c|c|c|c|c|}
\hline No & Nilai & Siswa & persentase & Kategori \\
\hline 1 & $\mathrm{X} \geq 75$ & 17 & $100 \%$ & Tuntas \\
\hline 2 & $\mathrm{X}<75$ & 0 & $0 \%$ & Belum tuntas \\
\hline
\end{tabular}

Mencermati data pada tabel 4 di atas dapat dilihat bahwa persentase ketuntasan siswa mencapai $100 \%$ dan ketidak tuntasan mencapai $0 \%$. Hasil tersebut mengindikasikan bahwa terjadi peningkatan persentase ketuntasan dari silus 1 sebesar $70,59 \%$ menjadi $100 \%$ pada siklus 2 atau mengalami peningkatan sebesar $29,41 \%$.

\section{Pembahasan}

Penerapan metode SQ3R terhadap peserta didik kelas X SMK Muhammadiyah Watansoppeng berhasil meningkatkan keterampilan membaca siswa. Hasil tersebut dapat dilihat sebagaimana dalam tabel 1,2,3 dan 4 di atas yang menujukkan ada peningkatan hasil belajar siswa yaitu keterampilan membaca. Sebagaimana dalam tabel 1 bahwa skor rata-rata keterampilan membaca siswa yaitu 79,23 dengan nilai mínimum yaitu 70 dan maksimum 90 . Untuk ketuntasan belajar yaitu 75 yang berarti masih ada beberapa siswa yang belum tuntas. Berdasarkan tabel ketuntasan sebagaimana dalam tabel 2 yaitu ketuntasan mencapai 70,59\% yang berarti bahwa masih ada $29,41 \%$ yang belum tuntas.

Berdasarkan pengamatan penulis bahwa ada beberapa kelemahan yang dijumpai dalam penerapan SQ3R dalam siklus 1 tersebut. Setelah dilakukan refleksi maka ditemukan kelemahan antara lain:

Langkah 1: Survey

Pada langkah ini sebagian peserta didik kurang menyediakan waktu untuk diri mereka mengenal secara keseluruhan naskah bacaan yang disediakan. Peserta didik langsung membaca naskah bacaan yang disediakan yaitu" Wayang".

Langkah 2: Question

Terhadap tahap ini masih ditemukan kelemahan pada peserta didik yakni kurang mempersiapkan pertanyaan yang berasal dari peserta didik sendiri mengenai pertanyaan seputar wacana tersebut misalnya" apa, siapa, kapan, mengapa, bagaimana tentang hal-hal yang berkaitan dengan bacaan. Ketika peneliti bertanya kepada peserta didik tentang berapa yang 
sudah mempersiapkan pertanyaan dalam diri mereka sendiri, ternyata ada 6 yang belum melakukan hal tersebut.

Langkah 3: Read

Secara keseluruhan dalam langkah ini peserta didik sudah melakukan kegiatan membaca hanya saja tingkat konsentrasi mereka berbeda oleh karena perbedaan mereka pada langkah pertama dan kedua dalam melakukan survey dan pertanyaan dalam diri mereka.

Langkah 4: Recite

Pada langkah ini juga masih nampak kelemahan yaitu beberapa peserta didik tidak membuat catatan-catatan yang telah mereka baca.

Langkah 1: Review

Pada langkah ini sebagian besar telah dilakukan dengan baik oleh peserta didik yaitu mengulang kembali apa yang perlu dibaca dipertegas untuk didapatkan jawabannya. Hanya saja oleh karena beberapa langkah sebelumnya yang belum dilakukan dengan baik maka langkah terakhir (review) kurang optimal.

Atas beberapa kelemahan yang ditemukan dalam siklus tersebut maka selanjutnya dilakukan perencanaan untuk dilanjutkan pada siklus 2 dengan tetap mengulang metode SQ3R. adapun perbandingan hasil siklus 1 dengan siklus 2 nampak pada tabel $3 \mathrm{~d}$ atas. Untuk rata-rata mengalami peningkatan sebesar 10,06. Sedangkan mode mengalami peningkatan dari 74 menjadi 85. Nilai mínimum dari 70 menjadi 80, nilai maksimum dari 90 menjadi 98. Selanjuntya untuk ketuntasan sebagaimana dalam tabel 4 di atas yakni $100 \%$.

Hasil penelitian ini sejalan dengan temuan penelitian (Agustina \& Hariyadi, 2018; Riadi, 2015) bahwa metode SQ3R dapat meningkatkan keterampilan membaca. Hasil penelitian yang dilakukan oleh Agustina \& Hariyadi serta Riadi dilakukan terhadap subjek penelitian mahasiswa sedangkan hasil penelitian yang dilakukan oleh penelitian sekarang adalah terhadap subjek siswa SMK. Proses belajar adalah proses yang berkaitan dengan proses kognitif seseorang. Koginitif menurut Chaplin sebagaimana dikutip oleh Maslukiyah \& Rumondor (2020) adalah bahwa suatu ranah yang berkaitan dengan psikologis manusia yang meliputi prilaku mental yang berkenaan dengan pertimbangan, pemahaman, pengolahan informasi, pemacaan masalah, kesengajaan dan keyakinan. Menurut teori belajar Jean Piaget bahwa ada empat tahap perkembangan kognitif seseorang. Tahap pertama dinamakan tahap sensori motor yakni terdapat pada usia 0-2 tahun. Tahap ini ditandai persepsi anak terhadap diri serta lingkungan dimana dia verada masih sederhana serta kemampuan motoriknya mulai berkembang secara perlahan. Tahap kedua yaitu Tahap para-operasional formal bagi anak usia dua sampai tujuh tahun, ditandai dengan mulai berkembangnya konsep intuitif anak. Tahap ketiga yaitu tahap operasional konkret bagi anak usia sembilan sampai 11 Tahun. Tahap ini dicirikan dengan kemampaun berpikir logis sudah terbentuk maskipun terbatas terhadap halhal yang sifatnyaa konkret. Tahap keempat yaitu Tahap operasional formal yang terjadi pada usia sebelas tahun ke atas. Tahap ini ditandai dengan kemampuan anak untuk berpikir abstrak, logis, anak mampu berpikir ilmiah dengan membuat hipotesa, mampu menganalisis dan membuat kesimpulan terhadap suatu fenomena (Santrock, 2007, hal.54).

Peserta didik dengan kelas $X$ pada jenjang SMK termasuk dalam tahap operasional formal yang berarti anak sudah mulai mampu berpikir ilmiah dengan membuat hipotesa, menganalisis, dan menarik kesimpulan ada suatu fenomena. Oleh karena itu penerapan metode SQ3R sudah tepat untuk dilakukan. Menurut Ginsburg dan Opper, sebagaiman dikutip dalam Suparno (2001) bahwa seseorang pada tahap operasional formal mempunyai tingkat ekuilibrium yang tinggi, dan oleh karenanya dia dapat berpikir secara efektif dan fleksibel, anak tersebut mampu menghadapi suatu persoalan yang sifatnya rumit, serta ia dapat berpikir fleksibel karena dapat melihat semua unsur dan kemungkinan yang ada. Alasan mengapa ia bisa berpikir efektif karena ia dapat mengidentifikasi pemikiran mana yang cocok untuk persoalan yang dihadapi.

Ketika proses pembelajaran Bahasa Indonesia belangsung dengan penerapan metode SQ3R kemampuan berpikir kritis peserta didik diperlukan. Untuk dapat melakukan tahap 
Survey, Question, Read, Recite dan review maka diperlukan kematangan berpikir untuk melihat bagian-bagian penting dalam wacana tersebut. Oleh karena itu tahap survey dan Read dibutuhkan speed Reading (membaca cepat). Menurut Nurhadi (1989) bahwa untuk meningkatkan kecepatan membaca dapat dilakukan sebagai berikut: pertama, sebaiknya pembaca membaca pada kelompok kata bukan pada kata demi kata. Jikalau hal ini sudah menjadi suatu kebiasanaan, maka sebaiknya melihat terbiasa untuk membaca satuan kalimat yang lebih tinggi dari kata. Kedua, Sebaiknya menghindari suatu pengulangan bacaan pada kalimat tertentu uatamanya kalimat baru atau dianggap sulit karena hal tersebut hanya akan membuang banyak waktu. Ketiga, untuk awal dan akhir kalimat diupayakan tidak terlalu lama membacanya karena bisa saja membuat pembaca lupa apa yang telah dibacanya. Akibat dari hal itu adalah hubungan antar kalimat atau antar paragrap sulit untuk dimaknai. Keempat, untuk menjadi pembaca yang efektif diupayakan agar dapat menangkap kata kunci dari suatu kalimat dan atau suatu paragraph.

Pada tahap questions (bertanya) dibutuhkan kemampuan untu menemukan jawaban atas pertanyaan diri sendiri. Pertanyaan tersebut antara lain "siapa, apa, kapan, diamana, mengapa dan bagiamana dari judul yang kita baca (National Behaviour Support Service, n.d.). Pada siklus 2 kemampuan untuk membuat pertanyaan ini dan dijawab berdasarkan judul bacaan yang diberikan dimaksimalkan kepada peserta didik. Beberapa peserta didik yang awalnya mengalami kesulitan untuk menemukan jawaban lambat laun terbiasa pada tahap ini.

Pada tahap read peserta didik membaca wacana dan mendapatkan jawaban, baik jawaban atas pertanyaan pada tahap questions maupun jawaban atas pertanyaan yang diberikan oleh guru.pada tahap recite peserta didik menuliskan dengan kata-kata sendiri apa yang telah mereka baca, menuliskan hal-hal penting dari tiap paragrap serta summary map (kesimpulan). Pada tahap review peserta didik melihat kembali wacana dengan memperhatikan jawaban yang telah diberikan. Tahap ini mengkomfirmasi antara jawaban dengan wacana yang diberikan.

Berdasarkan temuan penelitian ini bahwa ada kelemahan-kelemahan pada siklus 1 demikian pula pada siklus 2. Penerapan metode SQ3R perlu memang pelatihan berulang kepada peserta didik dan guru sebagai fasilitator harus mampu membawa pemikiran peserta didik terhadap substansi setiap langkahnya. Sebagaimana menurut Fisher \& Frey dalam Huda (2014) bahwa metode SQ3R mengahruskan guru untuk melakukan hal-hal sebagai berikut:

1) Gunakan lima langkah metode $S Q 3 R$ dengan cara memilih salah satu wacana untuk dibaca;

2) Lakukan kegiatan menyurvey, bertanya, membaca, mengutarakan ulang dan mereview terhadap wacana yang disediakan;

3) Guru memastikan bahwa setiap tahap tersebut dilakukan dengan baik oleh peserta didik;

4) Selanjutnya peserta didik diminta untuk mereview catatan-catatan siswa dan merefleksikan prosesnya dalam mengimplementasikan SQ3R;

5) Peserta didik tidak langsung mahir dengan metode tersebut, oleh karenanya peran guru untuk membantu peserta didik dalam mencapai tujuan tersebut.

Studi ini tidak terlepas dari adanya kelemahan-kelemahan akan tetapi dengan penetapan indikator dengan tingkat ketuntasan individu yaitu 75 sehingga dapat ditarik suatu kesimpulan bahwa implementasi metode SQ3R ini mampu mendorong keterampilan membaca siswa. Hasil penelitian ini sejalan dengan temuan penelitian Syamsiah, Adnan \& Suhriana (2012) bahwa penerapan metode SQ3R mampu mengoptimalkan hasil belajar dan aktivitas siswa.

\section{KESIMPULAN}

Merujuk pada hasil temuan análisis data di atas, dapat ditarik suatu kesimpulan bahwa implememtasi metode SQ3R (Survey, Question, Read, Recite dan Review) mampu meningkatkan keterampilan membaca siswa kelas X SMK Muhammadiyah Watansoppeng. Hasil penelitian ini dapat dikembangkan pada mata rumpun mata pelajaran lain seperti pelajaran Bahasa Inggris, Sejarah dan pelajaran lain yang menunutut pemahaman keterampian membaca. Tentu saja guru sebagai fasilitator menjadi titik tumpu untuk mengarahkan peserta didik di setiap langkahnya. 


\section{DAFTAR PUSTAKA}

Agustina, R. \& Hariyadi 2018. Penerapan metode SQ3R dan metode PQ3R terhadap keterampilan membaca pada mahasiswa. 3(2): 69-80.

Ahmadi, A. \& Prasetyo, J.T. 2005. strategi belajar mengajar. Bandung: Pustaka Setia.

Djamarah 2006. Strategi Belajar Mengajar. Jakarta: Rineka Cipta.

Huda, M. 2014. Model-Model Pengajaran dan Pembelajaran. Jogjakarta: Pustaka Pelajar.

Maslukiyah, N. \& Rumondor, P. 2020. Implementasi Konsep Belajar Humanistik pada Siswa dengan Tahap Operasional Formal di SMK Miftahul Khair. Psikologika: Jurnal Pemikiran dan Penelitian Psikologi, 25(1): 97-110.

National Behaviour Support Service n.d. Get Studying with the SQ3R Method.

Nurhadi 1989. Bagaimana meningkatkan kemampuan membaca? Bandung: Sinar Baru.

Riadi, B. 2015. KEMAMPUAN MEMBACA KRITIS DENGAN MENGGUNAKAN TEKNIK SQ3R MAHASISWA PROGRAM STUDI PENDIDIKAN BAHASA DAN SASTRA INDONESIA. Aksara: Jurnal bahasa dan sastra, 16(2): 137-144.

Santrock, J.W. 2007. Psikologi Pendidikan. Edisi Kedua. Jakarta: Kencana Prenada Media Group.

Soedarso 2000. Sistem Membaca Cepat dan Efektif. Jakarta: Gramedia Pustaka Utama.

Somadayo 2011. Membaca. Sidoarjo: Masmedia Buana Pustaka.

Suparno, P. 2001. Teori Perkembangan Kognitif Jean Piaget. Yogyakarta: Kanisius.

Susanti, S., Purmintasari, Y.D. \& Suwarni 2016. Pengaruh Penerapan Metode Pembelajaran SQ3R (Survey, Question, Read, Recite, and Review) Terhadap Hasil Belajar Mahasiswa Prgram Studi Pendidikan Sejarah IKIP PGRI Pontianak. Edukasi: Jurnal Pendidikan, 13(1): 97-104.

Syamsiah, Adnan \& Suhriana 2012. Penerapan Metode SQ3R ( Survey, Question, Read, Recite, Review ) untuk Meningkatkan Aktivitas dan Hasil Belajar Biologi Siswa kelas VIIIA SMP Negeri 1 Lamuru Kabupaten Bone I. Jurnal Sainsmat, I(1): 100-108. Tersedia di ojs.unm.ac.id/index.php/sainsmat.

Trianto 2010. Mendesain Model Pembelajaran Inovatif-Progresif: Konsep, Landasan, dan Implementasinya pada Kurikulum Tingkat Satuan Pendidikan (KTSP). Jakarta: Kencana Prenada Media Group. 